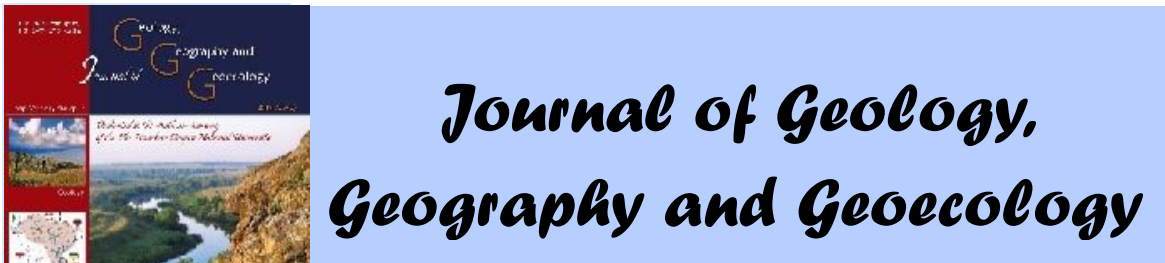

Journal home page: geology-dnu-dp.ua
ISSN 2617-2909 (print)

ISSN 2617-2119 (online)

Journ.Geol.Geograph.

Geoecology,

27(2), 202-212

doi: $10.15421 / 111845$

V. V. Grubinko, H.B. Humeniuk, V.O. Khomenchuk,

N.M. Garmatiy,V. B. Voytiuk, M.M. Barna.

Journ.Geol.Geograph.Geoecology, 27(2), 202-212

\title{
Ecotoxicological status and prognosis of the state of an urbanized hydroecosystem (on the example of the reservoir "Ternopil pond")
}

\author{
V. V. Grubinko ${ }^{1}$, H.B. Humeniuk ${ }^{1}$, V.O. Khomenchuk ${ }^{1}$, N.M. Garmatiy ${ }^{2}$, V. B. Voytiuk ${ }^{1}$, M.M. Barna \\ ${ }^{1}$ TernopilVolodymyr Hnatiuk National Pedagogical University,Ukraine, -mail: gumenjuk@chem-bio.com.ua \\ ${ }^{2}$ Ternopil Ivan Pului National Technical University, Ukraine, -mail: garmatiy.nat@meta.ua
}

Received 16.05.2018;

Received in revised form 26.06.2018;

Accepted 20.08.2018

Abstract. As a result of a complex hydroecological research on the reservoir "Ternopil Pond"and comparison of these data with environmental and quality water standards we assessed the environmental threat posed by the content of certain substances, and the ecotoxicological state of the pond in general. A high concentration of $\mathrm{HCO}_{3}$ - was found, but the critical factor of water pollution is the significant concentration of ammonia, as well as the excess over the permissible levels of sodium ions. Moreover, we found polymetallic contamination of the bottom sediments with a high ratio of biologically dangerous mobile forms, with the exception of iron, and the excess over permissible levels (MPS), which in some places was ten times higher than the norm. The high level of the content of mobile metals forms was found at sampling areaswith a considerable sedimentation. The content of the mobile form of copper exceeded the norm by 24-86 times, nickel - from 2 to 17 times, cobalt - 4-8 times. The content of the mobile form of cadmium exceeded the permissible norm by 5-80 times, and lead - by 4.5-12 times. It was established that the content of the metals of the essential group in the water of the reservoir wasbelow the permissible values, and in the places where active flushing waters are flowing high concentrations of copper wasfound. Among the nonessential metals, cadmium and lead were found with fairlyhigh cadmium content, which is biologically dangerous because of the toxicity of this metal. In case of changes in the hydrochemical balance, the mobility of metals may increase, which will substantially worsen the almost disastrous pollution of the reservoir with highly toxic and biologically hazardous metals.Economic-mathematical modeling and statistical methods based on correlation-regression analysis using Matlab software were used to investigate the influence of ammonium content on the water $\mathrm{pH}$ index. The correlation index is ststistically significant and amounts to 0.86 . This research will allow us to predict $\mathrm{pH}$ index of the water depending on the content of ammonium. The calculated elasticity coefficient shows that with an increase in ammonia by $10 \%$, the $\mathrm{pH}$ index of the water will vary by $8 \%$. In order to study the environmental situation in the near future, namely the content of metals in the bottom sediments, a forecast of the content of such metals as magnesium and cobaltfor the next two seasonal periods according to the theory of Markov chains has been made. This theory allows us to make predictions of the factor, taking into account the possibility of random effects on the environment, and investigates the greatest probability of presence of a factor in a certain numerical parameter.

Key words: water, bottom sediments, elasticity coefficient, correlation-regression analysis.

\section{котоксикологічний ст тус і прогнозув ння ст ну урб нізов ної гідроекосистеми (н прикл ді водосховищ " ернопільський ст в")}

. . рубінко $^{1}$, . . уменюк ${ }^{1}$, . . оменчук ${ }^{1}$, . . рм тій $^{2}, \ldots$ ойтюк ${ }^{1}$. . . рн

1 ернопільський н ціон льний пед гогічний університетім. . н тюк, ернопіль, кр їн, -mail: gumenjuk@chem-bio.com.ua

2 ернопільський н ціон льний технічний університет ім. . улюя, ернопіль, кр їн , -mail: garmatiy.nat@meta.ua

нот ція. результ ті комплексного гідроекологічного дослідження водосховищ « ернопільський ст в» шляхом порівняння отрим них пок зників з екологічними норм тив ми т ст нд рт ми якості н вколишнього середовищ оцінено екологічну небезпеку вмісту окремих речовин т екотоксикологічну ситу цію в цілому. иявлено високі концентр ції $\mathrm{O}_{3}{ }^{-}$i, критичним ф ктором у водоймі є н копичення мі ку у зн чних концентр ціях, т кож зн чне перевищення допустимих рівнів для йонів н трію, вст новлено полімет лічне з бруднення мулу з високою і біологічно небезпечною, крім з ліз , ч сткою рухомих форм мет лів т перев ж нням допустимих рівнів у окремих місцях у десятки р зів проти норми, відміче- 
но високий рівень вмісту рухомих форм мет лів, які вст новлено у точк х з зн чним 3 муленням. нструмент рієм економіко-м тем тичного моделюв ння т ст тистичних методів н основі кореляційно-регресійного н лізу 3 використ нням суч сних інформ ційних систем типу Matlab досліджено міру впливу вмісту монію н кислотність води - пок зник кореляції $€$ досить в гомий т ст новить 0,86. роведене дослідження дозволить прогнозув ти кислотність води через вміст монію. озр хов ний коефіцієнт ел стичності свідчить, що при збільшенні монію н $10 \%$ зн чення р води буде змінюв тись н 8\%. ля дослідження екологічної ситу ції н н йближчу перспективу, с ме вмісту мет лів у донних відкл д х, здійснено прогноз ситу ції по вмісту мет лів н н йближчі дв сезонні періоди згідно теорії л нцюгів рков . н теорія дозволяє здійснюв ти прогнози чинник, вр ховуючи можливість вип дкових впливів н середовище, т досліджується н йбільш ймовірність перебув ння чинник в певному числовому п р метрі.

лючові слов : вод , донні відкл ди, коефіцієнт ел стичності, кореляційно-регресійний н ліз.

Introduction. The attention paid both to the study and solving of environmental problems of fresh water ecosystems of inland water bodies is increasing due to the constantly increasing pollution (Romanenko etal., 2008; Shannon etal., 2011). Water quality is a limiting factor for water use in the face of a sharp increase in demand for fresh water (MyslyvaandKot, 2011). In recent decades, particularly dangerous for deterioration of the quality of natural waters are heavy metals (HM), which are considered to be the most dangerous for biota due to their toxicity and the ability to accumulate in hydrobionts (Nasrabadi, 2015; Perales etal. 2006). They belong to a class of conservative pollutants which do not decompose in the migration of trophic chains, they have mutagenic and toxic effects, greatly reduce the rate of flow of biochemical processes in aquatic organisms (Maliket al., 2014; Abubakar et al., 2015; Rashed 2001). Some of them are toxic even at very low concentrations (Myslyvaand Kot I., 2011), and such important elements as $\mathrm{Fe}, \mathrm{Cu}$ and $\mathrm{Zn}$, at elevated concentrations can also be biologically dangerous (Manoj etal., 2012).

First of all, the research related to the study of hydrochemical levels of pollution is relevant and, consequently, it is important to analyse their impact on the reactivity and self-sustainability of hydrobionts groups that provide the productivity and ductility of hydro ecosystems, their resistance to pollution and self-purifying capacity. Such studies, on the one hand, allow one to predict the possible consequences of pollution, and on the other hand, to model and plan measures to restore the natural status of an ecosystem, which supports the quality of water and the recreational and resource potential of reservoirs (Romanenko et al, 2015,Nesaratnam and Suresh, 2014, Correl, D.L. 1998). In order to predict and elaborate proposals for restoration measures in regulated freshwater ecosystems, we examined hydrochemical, toxicological and hydrobiological parameters that reflect the level of contamination, quantitative and qualitative characteristics of the development of aquatic organisms, as well as the effect of toxic factors on the water ecosystem of the reservoir Ternopil Pond (Romanenko, 2015; Grubinko et al.,2013).
The use of modeling tools and statistical analysis when studying the ecotoxicological situation of hydrosystems is relevant in modern conditions. The abovementioned problems are studied by modern scholars (Akin et al,2011; Budka et al, 2013). It is necessary to study the question of sources and ways of contamination of hydroecosystems of ribbon type reservoirs in the conditions of loading of various environmental pollutants (heavy metals, etc.), violation of the hydrochemical and hydrobiological regime in ecosystems, the development of the process of "eutrophication" (flowering) in reservoirs, the quality of the water environment and water, ways of preserving and increasing biodiversity, ensuring the sustainability of the succession series (development) of reservoir ecosystems in order to increase their environmental sustainability, expanding capacities for recreational and economic use of water and biological resources in accordance with the requirements of the environmental norms of Ukraine and the EU Water Framework Directive 2000/60 (Directive ..., 2000), maintaining on this basis a stable social and environmental situation of cities, restoration, protection and rational use of natural resources. The model of the ecotoxicological assessment and forecast of the ecosystem "Ternopil pond" can be considered as the basis for developing measures for preservation and optimization of recreational and water use of internal reservoirs of the lagoon water system of urbanized territories of Ukraine (Grubinko etal., 2013).In a view of the above, the purpose of our research is to determine the control variables (the content of heavy metals and some physical and chemical indicators of water) based on the analysis of the current state of the object, the implementation of which allows for the desired behaviour or state of the object of nature use.

Materials and methods. 1. Sites of research and their ecological characteristics. The natural water reservoir "Ternopil Pond" served as the object of study. Taking into account the pecularities of the hydroecological characteristics of this water body and factors of their formation, we selected monitoring sites described in Fig. 1. 


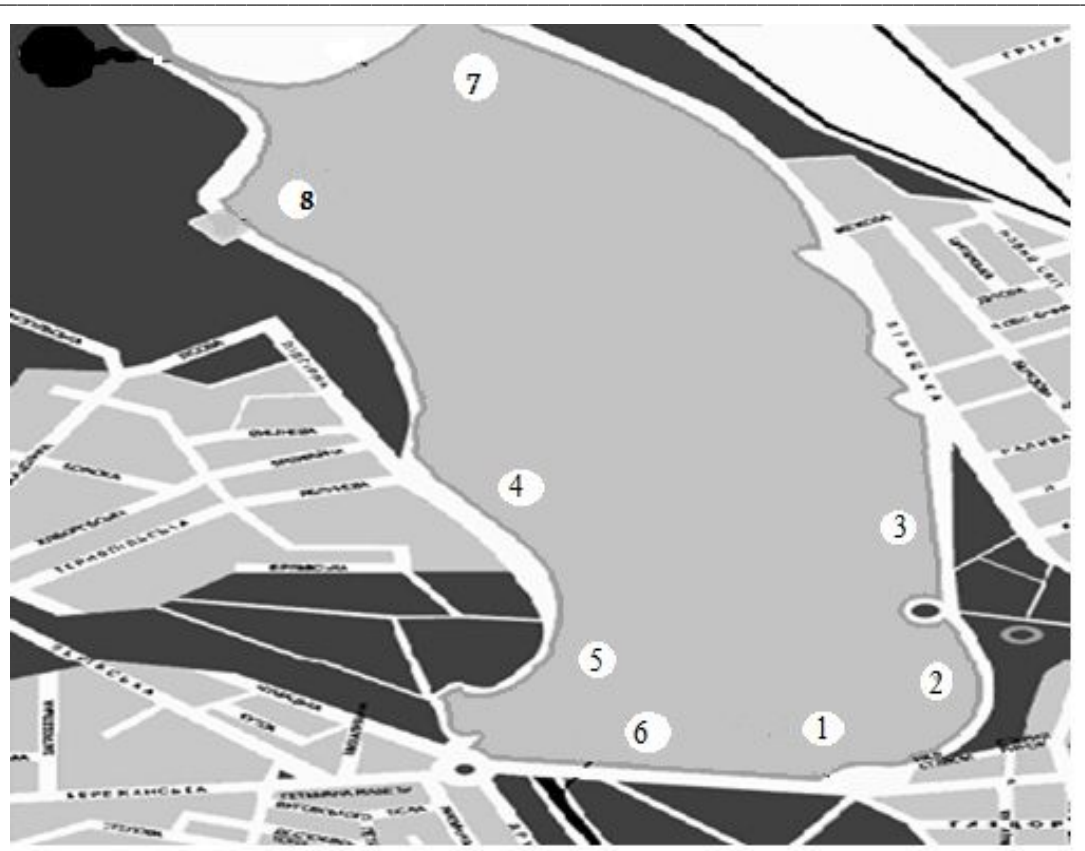

Fig. 1. The scheme of monitoring sites of the reservoir "TernopilPond" (1: 15000).

Sampling sites:

1 -areaof the backwater and the discharge of flushing waters from Ruska Street: the nearest distance from the shore (dam) - $25 \mathrm{~m}$, depth of sampling $-2.6 \mathrm{~m}$; characterized by the low intensity of water exchange, stagnant phenomena, inflow of coastal effluents, clogging up; bottom condensed, sandy-pebble with a significant number of shells of dead individuals and individual living molluses (up to $10-12 \mathrm{~cm}$ depth); medium vegetation was detected;

2 - area of backwaternear the pier: the nearest distance from the riverbank is $\sim 50 \mathrm{~m}$, sampling depth $-6.8 \mathrm{~m}$; characterized by the low intensity of water exchange, stagnant phenomena, inflow of coastal drainsfrom the hotel "Ternopil", clogging; the bottom with fallen leaves, sandmullish (to a depth of $60 \mathrm{~cm}$, there are no shells of dead individuals, live molluscs and vegetation);

3 - the area behind the island: the nearest distance from the bank is $\sim 40 \mathrm{~m}$, sampling depth is $4.7 \mathrm{~m}$; a natural barrier to the migration of pollutants from oil trap and discharge of flushing water through the canal (Rudka river) from Krushelnytska Street and the beach "Tsyhanka"; bottom of loose, sandy-mullish (to a depth of more than $90 \mathrm{~cm}$ there are no shells of dead individuals, live molluscs and vegetation);

4 - area opposite the Khutir restaurant: the nearest distance from the bank is $\sim 30 \mathrm{~m}$, sampling depth is $2.0 \mathrm{~m}$; is characterized by the flow of manmade emissions from the drainage and atmospheric precipitation from the territories of the "Dalnii Beach", the boats mooring and the Khutir restaurant, the bottom of medium-density, sandypebble (to a depth of about $50 \mathrm{~cm}$, there are single shells of dead individuals and live molluses and vegetation);

5 - area of the backwater and discharging flushingwater from the hotelHalychyna: the nearest distance from the bank is $\sim 50 \mathrm{~m}$, sampling depth is $5.0 \mathrm{~m}$; characterized by the low intensity of water exchange, stagnant phenomena, inflow of coastal effluents, clogging up; bottom of loose, sandymullish (to a depth of more than $60 \mathrm{~cm}$ there are no shells of dead individuals and live molluscs, there is sparse/poor vegetation);

6 - admissible area: the nearest distance from the shore (dam) - $30 \mathrm{~m}$, depth of sampling - 2.4 $\mathrm{m}$; near the main channel and the gateways, is characterized by high intensity of water exchange; bottom condensed, sandy-pebble with a significant number of shells of dead individuals and individual live molluscs (to a depth of 10-12 cm); medium vegetation was detected;

7 - area from the village of Bila: the nearest distance from the shore is $\sim 30 \mathrm{~m}$, sampling depth is $3.7 \mathrm{~m}$; flushing from the village of Bila; bottom of loose, sandy-mullish (to a depth of about $60 \mathrm{~cm}$ there are no shells of dead individuals and live molluscs, sparse/poor vegetation);

8 - distant beach area: the nearest distance from the river bank is $\sim 25 \mathrm{~m}$, depth of sampling $1.8 \mathrm{~m}$; is characterized by the flow of flushed waters with runoff and atmospheric precipitation from the territories of the private sector of the village of Kutkivtsi and "Dalnii" beach, the bottom is medium-dense, sandy-mullish (to a depth of about $40 \mathrm{~cm}$ there are single shells of dead molluscs).

The selected areas take into account the main sources of pollution with flushing water and water collectors (sites 1, 3, 4, 7, 8) and the hydrological 
regularities of migration and accumulation of toxic substances and correlate with the places of eutrophicationin the reservoir that were observed in previous years. (Grubinko, etal. 2013., Gumenyuk, 2003).

Methods of hydrochemical research. All measuring instruments used in the research are standardized and endorsed with the expertise of the State Enterprise "Ternopil Scientific and Production Center of Standardization, Metrology and Certification" by the issue of certificates of verification of the regulated regulatory instrument of measuring equipment from 14.09.2016: atomic absorption spectrophotometer C $115 \mathrm{M}$ (Certificate No. 743 -F); ionizer EV 74 (Certificate No. 745-F); spectrophotometer SF 46 (Certificate No. 742-F); Fluorocarbonometer KFK-2 (Certificate No. 744F); Oxygenizer AHA-101,1 V1 (Certificate No. 741-F); liquid chromatograph "Crystal 200" (certificate number 266-F).

The number of samples at each site was repeated three times. The measurements are given as an arithmetic mean of three measurements at each sampling site.

The content of heavy metals in water and sediment was determined by atomic absorption spectrophotometry (Ermachenko, 1997).

Ammonium cations in water and sediment were determined colorimetrically (Romanenko, 2006). The method is based on the ability of ammonia and ammonium ions to form a yellowish brown colour of the compound with a Nessler reagent.

The determination of the concentration of nitrates was carried out by colorimetric method with phenol disulfonic acid (Romanenko, 2006). The method is based on the reaction between nitrates and phenol disulfonic acid to form nitroderivative phenols, which form yellow compounds with alkali compounds.

Determination of nitrites was carried out colorimetrically (Romanenko, 2006). The methods are based on the formation of azure colour of red colour when passing the reaction of nitrite ions with the Grissa reagent.

The ecological danger of the content of certain substances and the ecotoxicological situation as a whole were assessed by comparing the indicators with environmental norms and environmental standards: toxicity on the basis of comparison of indicators with the values of MPC (Maximum permissible concentrations of harmful substances in water of water reservoirs of household and drinking and cultural and household purposes) (Rules..., 1999), and ecotoxicological danger in accordance with the "List of pollutants for determining the chemical status of the arrays of surface and ground water and ecological potential of anartificialor substantially modified surface water massif" (List ..., 2017).

In order to study the effect of ammonium on water $\mathrm{pH}$ index, the statistical analysis methods, namely correlation-regression analysis (Akin B.S., 2011), are used, the correlation index is quite significant and is 0.86 , the study will allow adjustment of the water $\mathrm{pH}$ index through the content of ammonium. The calculated elasticity coefficient shows that with an increase in ammonia by $10 \%$, the water $\mathrm{pH}$ index will change by $8 \%$. Also, the prediction of the content of heavy metals in the bottom sediments by the method of Markov chain theory is carried out. This theory allows us to make predictions of the factor, taking into account the possibility of random effects on the environment, and investigates the greatest probability of presence of a factor in a certain numerical parameter (Rogatunskiy R. nd Garmatiy N.2015).

\section{Results}

$\mathrm{pH}$ Index of water (Table 1).

able 1. $\mathrm{pH}$ index of water $(\mathrm{M} \pm \mathrm{m})$

\begin{tabular}{|c|c|c|c|c|c|c|c|c|c|}
\hline Indexes & range & \multicolumn{7}{|c|}{ Selection Sites } \\
\cline { 3 - 10 } & & 1 & 2 & 3 & 4 & 5 & 6 & 7 & 8 \\
\hline $\mathrm{p}$ & $1-14$ & $8.02 \pm 0.05$ & $7.31 \pm 0.03$ & $7.40 \pm 0.04$ & $7.52 \pm 0.03$ & $7.39 \pm 0.02$ & $7.52 \pm 0.03$ & $7.24 \pm 0.05$ & $7.46 \pm 0.02$ \\
\hline
\end{tabular}

At all the sites investigated, the water has a $\mathrm{pH}>7$, which contributes to the presence of carbon dioxide in the form of a hydrocarbonate ion, providing an environmentally acceptable gas regime of water and the absence of obsolescent phenomena. The increase of $\mathrm{pH}$ of watermay be the decay of organic sucstances in the bottom layer and the sludge with the formation of ammonia and the salinity of the reservoir with alkaline equivalents of flushing origin. High alkalinity of water also contributes to the transition of a significant amount of ammonia to highly toxic ammonia, which degrades the ecotoxicological situation of the reservoir, since ammonia is 200 times more toxic than ammonium $\left(\mathrm{MAC} \mathrm{NH}_{4}+=2.0 \mathrm{mg} / 1 ; \mathrm{HDCNH}_{3}=0.01 \mathrm{mg} / \mathrm{l}\right)$.

2. The content of nitrogen compounds (Table 2,3). 


\begin{tabular}{|c|c|c|c|c|c|c|c|c|c|}
\hline \multirow{2}{*}{$\begin{array}{c}\text { Forms of } \\
\text { nitrogen }\end{array}$} & \multirow{2}{*}{$\begin{array}{c}\mathrm{MPC}, \\
\mathrm{mg} / \mathrm{l}\end{array}$} & \multicolumn{8}{|c|}{ Sampling sites } \\
\hline & & 1 & 2 & 3 & 4 & 5 & 6 & 7 & 8 \\
\hline $\begin{array}{c}\mathrm{NH}_{4}^{+}, \\
\mathrm{mg} / \mathrm{l}\end{array}$ & 2.0 & $20.0 \pm 1.8$ & $67.0 \pm 3.4$ & $68.0 \pm 4.6$ & $62.0 \pm 2.9$ & $60.0 \pm 4.3$ & $31.0 \pm 2.3$ & $69.0 \pm 2.7$ & $57.0 \pm 3.4$ \\
\hline $\begin{array}{c}\mathrm{NO}_{2}^{-}, \\
\mathrm{mg} / \mathrm{l}\end{array}$ & 3.0 & $\begin{array}{l}0.005 \pm \\
0.0004\end{array}$ & $\begin{array}{l}0.007 \pm \\
0.0003\end{array}$ & $\begin{array}{l}0.15 \pm \\
0.001\end{array}$ & $\begin{array}{l}0.06 \pm \\
0.004\end{array}$ & $\begin{array}{l}0.09 \pm \\
0.008\end{array}$ & $\begin{array}{l}0.01 \pm \\
0.002\end{array}$ & $\begin{array}{c}0.17 \pm \\
0.03\end{array}$ & $\begin{array}{l}0.12 \pm \\
0.007\end{array}$ \\
\hline $\begin{array}{c}\mathrm{NO}_{3}^{-}, \\
\mathrm{mg} / \mathrm{l}\end{array}$ & 45.0 & $\begin{array}{l}0.005 \pm \\
0.0003\end{array}$ & $\begin{array}{c}0.1 \pm \\
0.006\end{array}$ & $\begin{array}{l}0.05 \pm \\
0.004\end{array}$ & $\begin{array}{l}0.09 \pm \\
0.003\end{array}$ & $\begin{array}{c}0.14 \pm \\
0.04\end{array}$ & $\begin{array}{l}0.06 \pm \\
0.003\end{array}$ & $\begin{array}{l}0.08 \pm \\
0.004\end{array}$ & $\begin{array}{l}0.16 \pm \\
0.008\end{array}$ \\
\hline $\begin{array}{c}\mathrm{NH}_{4}^{+}: \\
\mathrm{NO}_{2}: \\
\mathrm{NO}_{3}^{-}, \%\end{array}$ & - & $\begin{array}{c}100: \\
0.025: \\
0.025\end{array}$ & $\begin{array}{c}100: \\
0.01: \\
0.15\end{array}$ & $\begin{array}{c}100: \\
0.22: \\
0.07\end{array}$ & $\begin{array}{l}100: \\
0.10: \\
0.15\end{array}$ & $\begin{array}{l}100: \\
0.15: \\
0.23\end{array}$ & $\begin{array}{c}100: \\
0.03: \\
0.19 \\
\end{array}$ & $\begin{array}{c}100: \\
0.25: \\
0.12 \\
\end{array}$ & $\begin{array}{l}100: \\
0.21: \\
0.28 \\
\end{array}$ \\
\hline
\end{tabular}

From the data obtained it is evident that in the water and in the sediments (sludge) there was an active ammonification resulting from the decomposition of organic matter that settled during the winter and was oxidized. The most polluted ammonia water is in the streams of flow from the village of Bila, stagnant water near the "Nadstavna Church", behind the island from the side of "Tsyhanka" beach, near the restaurant "Khutir" and near the boat station (exceeding the MPC by almost 30 times). Less contaminated due to leakage are areas near the dam (water drain - western and eastern sites 6 and 1) (exceeding the MPC by 10-15 times).

The most polluted ammonia sludge is on sites near the "Nadstavna Church", from the side of the runoff from the village of Bila and behind the island from the side of "Tsyganka" beach (exceeding the MPC by almost 100-150 times).

Data on the content of ammonium, nitrite and nitrate in the bottom sediments are presented in Table 3.

able 3. The content of ammonium nitrites and nitrates in the bottom sediments $(M \pm m)$

\begin{tabular}{|c|c|c|c|c|c|c|c|c|}
\hline \multirow[t]{2}{*}{ Forms of nitrogen } & \multicolumn{8}{|c|}{ Sampling sites } \\
\hline & 1 & 2 & 3 & 4 & 5 & 6 & 7 & 8 \\
\hline $\begin{array}{l}\mathrm{NH}_{4}^{+}, \mathrm{mg} / 100 \mathrm{~g} . \\
\text { over dry ground }\end{array}$ & $95.5 \pm 5.3$ & $219.0 \pm 4.7$ & $325.1 \pm 8.9$ & $85.4 \pm 7.3$ & $120.5 \pm 6.7$ & $116.8 \pm 4.3$ & $265.2 \pm 9.1$ & $162.4 \pm 5.2$ \\
\hline $\begin{array}{c}\mathrm{NO}_{2}^{-}, \\
\mathrm{mg}_{\Gamma} / 100 \mathrm{~g} \\
\text { over dry ground }\end{array}$ & $5.5 \pm 0.3$ & $1.7 \pm 0.2$ & $1.6 \pm 0.1$ & $1.5 \pm 0.2$ & $1.5 \pm 0.3$ & $2.1 \pm 0.2$ & $2.3 \pm 0.4$ & $1.7 \pm 0.2$ \\
\hline $\begin{array}{c}\mathrm{NO}_{3}^{-}, \\
\mathrm{mg} / 100 \mathrm{~g} \text { over dry } \\
\text { ground }\end{array}$ & $0.1 \pm 0.009$ & $3.0 \pm 0.09$ & $0.7 \pm 0.03$ & $1.2 \pm 0.07$ & $1.1 \pm 0.01$ & $0.8 \pm 0.03$ & $1.2 \pm 0.05$ & $0.9 \pm 0.02$ \\
\hline $\mathrm{NH}_{4}^{+}:$ & 100: & 100: & 100: & 100: & 100: & 100: & 100: & 100: \\
\hline $\mathrm{NO}_{2}^{-}:$ & 5.3: & 0.8 : & 0.5 : & 1.8: & 1.3: & 1.8: & 0.9 : & 1.0: \\
\hline $\mathrm{NO}_{3}^{-}, \%$ & 0.1 & 1.4 & 0.2 & 1.4 & 0.9 & 0.7 & 0.5 & 0.6 \\
\hline
\end{tabular}

Exceeding norms of nitrites and nitrates was not revealed - the levels in the water were much lower than the maximum permissible standards.

Hence, one of the critical factors for aquatic organisms, especially the bottom layer and sludge, is the ammonation and accumulation of ammonia in significant concentrations and its presence in the form of highly toxic $\mathrm{NH}_{3}$ due to the alkalinity of water.

Based on the correlation-regression dependence, we will investigate the effect of the ammonium content (Table 3) on the $\mathrm{pH}$ index of water (Table 2). The calculations are made in the software Matlab.

$\mathrm{Y}=[8.02 ; 7.31 ; 7.40 ; 7.52 ; 7.39 ; 7.52 ; 7.24 ; 7.46]$

$\mathrm{Y}=$

8.0200

7.3100

7.4000

7.5200

7.3900

\subsection{0}

7.2400

7.4600

$>\mathrm{X} 1=[20 ; 67 ; 68 ; 62 ; 60 ; 31 ; 69 ; 57]$

$\mathrm{X} 1=$

20

67

68

62

60

31

69

57

>> corrcoef $(\mathrm{X} 1, \mathrm{Y})$

ans $=$

$1.0000-0.8622$

$-0.8622 \quad 1.0000$

Correlation is strong and is 0,86

> $\operatorname{glmfit}(\mathrm{X} 1, \mathrm{Y})$

ans $=$

8.0855 


\section{$-0.0111$}

Regression equation $\mathrm{y}=8.0855-0.0111 \mathrm{x}$ Coefficient of elasticity $\mathrm{E}=(-$ $0.0111 * 57) /(8.0855+(-0.0111 * 57))$ $\mathrm{E}=-0.0849$

Also, the method of correlation-regression analysis investigated the effect of ammonium on the $\mathrm{pH}$ index of water, the effect is quite significant and is $86 \%$. The coefficient of elasticity was calculated on the basis of this value. The coefficient of elasticity suggests that with an increase in ammonia

by $10 \%$, the $\mathrm{pH}$ index of water will decrease by $8 \%$.
3. The content of metals (Table 4, 5).

Traditionally, according to the degree of biological danger, metals are divided into three groups: biogenic (necessary for organisms in high concentrations), essential (necessary for life in microconcentrations, exceeding of which adds up to toxicity), and nonessential (toxic in any concentrations). On the other hand, biological activity is manifested only by the so-called mobile forms (soluble, ionic). Therefore, the gross metal content in living environments reflects their total pollution and the degree of accumulation, and the biological hazard reflects the level of mobile forms.

Table 4. The content of metals in water $*(\mathrm{M} \pm \mathrm{m})$

\begin{tabular}{|c|c|c|c|c|c|c|c|c|c|}
\hline \multirow{2}{*}{$\begin{array}{c}\text { Content of } \\
\text { metals, } \\
\text { mg/l }\end{array}$} & \multirow{2}{*}{$\begin{array}{c}\text { MPS *mg/ } \\
1\end{array}$} & \multicolumn{8}{|c|}{ Selection sites } \\
\hline & & 1 & 2 & 3 & 4 & 5 & 6 & 7 & 8 \\
\hline \multicolumn{10}{|l|}{ Biogenic } \\
\hline Sodium & 200.0 & $\begin{array}{c}239.0 \pm \\
7.2\end{array}$ & $\begin{array}{c}212.0 \pm \\
11.7\end{array}$ & $\begin{array}{c}223.5 \pm \\
6.4\end{array}$ & $\begin{array}{c}217.2 \pm \\
5.9\end{array}$ & $\begin{array}{c}214.3 \pm \\
7.5\end{array}$ & $\begin{array}{c}228.5 \pm \\
6.0\end{array}$ & $\begin{array}{c}231.7 \pm \\
7.0\end{array}$ & $\begin{array}{c}212.4 \pm \\
9.3\end{array}$ \\
\hline Potassium & n.l & $\begin{array}{c}4.30 \pm \\
0.41\end{array}$ & $\begin{array}{c}4.55 \pm \\
0.37\end{array}$ & $\begin{array}{c}5.13 \pm \\
0.49\end{array}$ & $\begin{array}{c}4.85 \pm \\
0.32\end{array}$ & $\begin{array}{c}4.70 \pm \\
0.44\end{array}$ & $\begin{array}{c}5.40 \pm \\
0.35\end{array}$ & $\begin{array}{c}4.73 \pm \\
0.41\end{array}$ & $\begin{array}{c}4.45 \pm \\
0.22\end{array}$ \\
\hline Calcium & n.l. & $\begin{array}{c}7.19 \pm \\
0.67\end{array}$ & $\begin{array}{c}6.35 \pm \\
0.56\end{array}$ & $\begin{array}{c}3.08 \pm \\
0.36\end{array}$ & $\begin{array}{c}0.40 \pm \\
0.06\end{array}$ & $\begin{array}{c}1.30 \pm \\
0.04\end{array}$ & $\begin{array}{c}0.57 \pm \\
0.05\end{array}$ & $\begin{array}{l}3.8 \pm \\
0.12\end{array}$ & $\begin{array}{l}1.2 \pm \\
0.07\end{array}$ \\
\hline Magnesium & 40.0 & $\begin{array}{c}6.28 \pm \\
0.47\end{array}$ & $\begin{array}{c}25.88 \pm \\
1.64 \\
\end{array}$ & $\begin{array}{c}10.23 \pm \\
0.17\end{array}$ & $\begin{array}{l}8.29 \pm \\
0.75\end{array}$ & $\begin{array}{c}10.13 \pm \\
1.13\end{array}$ & $\begin{array}{c}6.65 \pm \\
0.55\end{array}$ & $\begin{array}{c}9.64 \pm \\
0.19\end{array}$ & $\begin{array}{c}7.68 \pm \\
0.33 \\
\end{array}$ \\
\hline \multicolumn{10}{|c|}{ Essential (toxic in high concentrations) } \\
\hline Iron & 0.3 & $\begin{array}{c}0.015 \pm \\
0.001\end{array}$ & $\begin{array}{l}0.005 \pm \\
0.0007\end{array}$ & $\begin{array}{l}0.004 \pm \\
0.0001\end{array}$ & $\begin{array}{l}0.001 \pm \\
0.0005\end{array}$ & $\begin{array}{l}0.002 \pm \\
0.0001\end{array}$ & $\begin{array}{l}0.005 \pm \\
0.0002\end{array}$ & $\begin{array}{l}0.004 \pm \\
0.0002\end{array}$ & $\begin{array}{c}0.002 \pm \\
0.00009\end{array}$ \\
\hline Cobalt & 0.1 & $\begin{array}{l}0.002 \pm \\
0.0002\end{array}$ & $\begin{array}{l}0.002 \pm \\
0.0001\end{array}$ & $\begin{array}{l}0.002 \pm \\
0.0001\end{array}$ & $\begin{array}{l}0.002 \pm \\
0.0001\end{array}$ & $\begin{array}{l}0.002 \pm \\
0.0001\end{array}$ & $\begin{array}{l}0.002 \pm \\
0.0001\end{array}$ & $\begin{array}{l}0.002 \pm \\
0.0001\end{array}$ & $\begin{array}{l}0.002 \pm \\
0.0001\end{array}$ \\
\hline Manganese & 0.1 & $\begin{array}{l}0.0002 \pm \\
0.00001\end{array}$ & $\begin{array}{l}0.0002 \pm \\
0.00001\end{array}$ & $\begin{array}{l}0.0002 \pm \\
0.00001\end{array}$ & $\begin{array}{l}0.0002 \pm \\
0.00001 \\
\end{array}$ & $\begin{array}{l}0.0002 \pm \\
0.00001 \\
\end{array}$ & $\begin{array}{l}0.0002 \pm \\
0.00001\end{array}$ & $\begin{array}{l}0.0002 \pm \\
0.00001 \\
\end{array}$ & $\begin{array}{l}0.0002 \pm \\
0.00001\end{array}$ \\
\hline Copper & 1.0 & $\begin{array}{c}0.065 \pm \\
0.003 \\
\end{array}$ & $\begin{array}{c}0.008 \pm \\
0.004 \\
\end{array}$ & $\begin{array}{c}0.042 \pm \\
0.006 \\
\end{array}$ & $\begin{array}{c}0.023 \pm \\
0.001 \\
\end{array}$ & $\begin{array}{l}0.15 \pm \\
0.001 \\
\end{array}$ & $\begin{array}{l}0.20 \pm \\
0.007 \\
\end{array}$ & $\begin{array}{c}0.036 \pm \\
0.003 \\
\end{array}$ & $\begin{array}{c}0.009 \pm \\
0.001 \\
\end{array}$ \\
\hline Nickel & 0.1 & $\begin{array}{l}0.0008 \pm \\
0.00001\end{array}$ & $\begin{array}{l}0.0008 \pm \\
0.00006\end{array}$ & $\begin{array}{l}0.0008 \pm \\
0.00005\end{array}$ & $\begin{array}{l}0.0008 \pm \\
0.00003\end{array}$ & $\begin{array}{l}0.0008 \pm \\
0.00002\end{array}$ & $\begin{array}{l}0.0008 \pm \\
0.00001\end{array}$ & $\begin{array}{l}0.0008 \pm \\
0.00002\end{array}$ & $\begin{array}{l}0.0008 \pm \\
0.00003\end{array}$ \\
\hline Zinc & 1.0 & $\begin{array}{l}0.0005 \pm \\
0.00002\end{array}$ & $\begin{array}{l}0.0005 \pm \\
0.00001\end{array}$ & $\begin{array}{l}0.0005 \pm \\
0.00003\end{array}$ & $\begin{array}{l}0.0005 \pm \\
0.00002\end{array}$ & $\begin{array}{l}0.0005 \pm \\
0.00001\end{array}$ & $\begin{array}{l}0.0005 \pm \\
0.00003\end{array}$ & $\begin{array}{l}0.0005 \pm \\
0.00001\end{array}$ & $\begin{array}{l}0.0005 \pm \\
0.00002\end{array}$ \\
\hline \multicolumn{10}{|c|}{ Non-essential (toxic) } \\
\hline Cadmium & 0.001 & $\begin{array}{l}0.0005 \pm \\
0.00001\end{array}$ & $\begin{array}{l}0.0005 \pm \\
0.00001\end{array}$ & $\begin{array}{l}0.0005 \pm \\
0.00002\end{array}$ & $\begin{array}{l}0.0005 \pm \\
0.00002\end{array}$ & $\begin{array}{l}0.0005 \pm \\
0.00001\end{array}$ & $\begin{array}{l}0.0005 \pm \\
0.00003\end{array}$ & $\begin{array}{l}0.0005 \pm \\
0.00001\end{array}$ & $\begin{array}{l}0.0005 \pm \\
0.00002\end{array}$ \\
\hline Lead & 0.03 & $\begin{array}{l}0.01 \pm \\
0.001 \\
\end{array}$ & $\begin{array}{c}0.01 \pm \\
0.0007 \\
\end{array}$ & $\begin{array}{c}0.01 \pm \\
0.0007\end{array}$ & $\begin{array}{c}0.01 \pm \\
0.0005\end{array}$ & $\begin{array}{c}0.01 \pm \\
0.0006\end{array}$ & $\begin{array}{c}0.01 \pm \\
0.0005 \\
\end{array}$ & $\begin{array}{c}0.01 \pm \\
0.0005\end{array}$ & $\begin{array}{c}0.01 \pm \\
0.0005 \\
\end{array}$ \\
\hline
\end{tabular}

Note: * - a mobileform; nl - not limited

In the water, excess over the maximum permissible levels was found only for sodium ions (Table 4), which, along with the sum of ions of other metals, indicates a significant salinity of the water of the pond, especially at the sites of active washings and drains from the coast: 1 and 6 - from the dam, 3 from side of Krushelnytska Street, 4 from the restaurant "Khutir", 7 from the "Novyi Svit" neighborhood and the village of Bila. Taking into account the nature of communal activities, it is possible that the main source of salinity is the use on the roads and side- walks of bulk salts and slags in the winter.
The content of metals of the essential group in the water is much lower than the maximum permitted values, which may be the result of their deposition in silicate phosphates, which form the soluble salts with these met-als. However, copper is found in high concentrations inthe areas of active flow of flushing water.Among nones-sential metals, only cadmium and lead have been found. Moreover cadmium content, although not reaching the maximum permissible levels, is quite high and biologically dangerous because of the extremely high toxicity of this metal, which is still mutagenic.In the silt (see Table 5), extremely high indexes of metals content of all investigated groups were detected. 
For the biogenic group of metals, low mobility (an exchange fund with water) is found to be $1-5 \%$, and the vast majority of them, most likely, are recorded in colloids, humic complexes of silt and other organic substances.Among the metals of the essential group, the excess of the norm of gross content for copper was found to be 18-67 times, nickel - 1.5-10 times, cobalt - 1.5-3 times, a high level of mobile zinc was established. The high level of accumulation of metals is set at sites with significant sedimentation, phosphate content and high $\mathrm{pH}$ values sites $2-5$, the least precipitated metal compounds in the admixture - sites 1 and 6.At the same time, guided by the principle of high toxicity of the mobile metals, it is worth mentioning that the iron in the silt is is mainly connected, and therefore biologically safe. As for other metals, the degree of their mobility, and, consequently, the biological threat, we can make a row: copper> nickel> manganese> cobalt> zinc. Among the metals of the essential group, the excess of the norm of the content of the mobile mold for copper was detected - 24-86 times, nickel - from 2 to 17 times, cobalt - 4-8 times, high level of iron and zinc.

Table 5. The content of metals in the bottom sediments

\begin{tabular}{|c|c|c|c|c|c|c|c|c|c|}
\hline \multirow{2}{*}{$\begin{array}{l}\text { Metal content } \\
\text { mg / kg dry } \\
\text { the sediment }\end{array}$} & \multirow{2}{*}{$\begin{array}{l}\text { MPS } \\
* \underset{m g}{ } / \\
\mathrm{m}^{3}\end{array}$} & \multicolumn{8}{|c|}{ Sampling sites } \\
\hline & & 1 & 2 & 3 & 4 & 5 & 6 & 7 & 8 \\
\hline \multicolumn{10}{|l|}{ Biogenic } \\
\hline Sodium & $\mathrm{nl}$ & $\begin{array}{l}\frac{18760.1}{215.6} \\
(1.2 \%)\end{array}$ & $\begin{array}{c}\frac{20465.3}{230.5} \\
(1.1 \%)\end{array}$ & $\begin{array}{c}24830.1 \\
315.3 \\
(1.2 \%)\end{array}$ & $\begin{array}{l}\frac{22680.5}{306.9} \\
(1.3 \%)\end{array}$ & $\begin{array}{c}33180.2 \\
389.1 \\
(1.1 \%)\end{array}$ & $\begin{array}{c}\frac{29040.5}{430.9} \\
(1.5 \%)\end{array}$ & $\begin{array}{c}\frac{28300.2}{339.6} \\
(1.2 \%)\end{array}$ & $\begin{array}{l}\frac{20860.3}{271.8} \\
(1.3 \%)\end{array}$ \\
\hline Potassium & $\mathrm{nl}$ & $\begin{array}{c}\frac{3909.1}{187.5} \\
(5 \%)\end{array}$ & $\begin{array}{l}\frac{5076.2}{250.9} \\
(5 \%)\end{array}$ & $\begin{array}{c}\frac{5863.2}{292.8} \\
(5 \%)\end{array}$ & $\begin{array}{l}\frac{5847.3}{292.7} \\
(5 \%)\end{array}$ & $\begin{array}{l}\frac{3546.5}{271.8} \\
(8 \%)\end{array}$ & $\begin{array}{l}\frac{3847.1}{271.9} \\
(7 \%)\end{array}$ & $\begin{array}{l}\frac{5984.2}{359.0} \\
(7 \%)\end{array}$ & $\begin{array}{l}\frac{4487.4}{224.3} \\
(5 \%)\end{array}$ \\
\hline Calcium & $\mathrm{nl}$ & $\begin{array}{c}\frac{186600}{5430} \\
(3 \%)\end{array}$ & $\begin{array}{l}\frac{188169}{5215} \\
(3 \%)\end{array}$ & $\begin{array}{c}\frac{164720}{5265} \\
(3 \%)\end{array}$ & $\begin{array}{l}\frac{89305}{3375} \\
(4 \%)\end{array}$ & $\begin{array}{c}\frac{192800}{5648} \\
(3 \%)\end{array}$ & $\begin{array}{l}\frac{199211}{7790} \\
(4 \%)\end{array}$ & $\begin{array}{c}\frac{176204}{7048} \\
(4 \%)\end{array}$ & $\begin{array}{l}\frac{99530}{3982} \\
(4 \%)\end{array}$ \\
\hline Magnesium & $\mathrm{nl}$ & $\begin{array}{c}\frac{25601.1}{212.3} \\
(0.8 \%)\end{array}$ & $\begin{array}{l}\frac{94442.3}{807.5} \\
(0.8 \%)\end{array}$ & $\begin{array}{c}\frac{105200.1}{1020.1} \\
(0.9 \%)\end{array}$ & $\begin{array}{l}\frac{107404.3}{1262.3} \\
(1.2 \%) \\
\end{array}$ & $\begin{array}{c}\frac{126902.4}{1200.1} \\
(0.9 \%) \\
\end{array}$ & $\begin{array}{l}\frac{81010.2}{634.9} \\
(0.7 \%) \\
\end{array}$ & $\begin{array}{c}\frac{117364.3}{1408.4} \\
(1.2 \%) \\
\end{array}$ & $\begin{array}{c}\frac{115020.2}{1380.2} \\
(1.2 \%) \\
\end{array}$ \\
\hline \multicolumn{10}{|c|}{$\begin{array}{l}\text { Essential } \\
\text { (toxic in high concentrations) }\end{array}$} \\
\hline Iron & n.1. & $\begin{array}{l}6110.1 \\
121.3 \\
(2 \%)\end{array}$ & $\begin{array}{c}\frac{22368.6}{438.6} \\
(2 \%)\end{array}$ & $\begin{array}{c}\frac{35436.7}{725.4} \\
(2 \%)\end{array}$ & $\begin{array}{c}\frac{45721.9}{933.1} \\
(2 \%)\end{array}$ & $\begin{array}{c}\frac{35955.0}{720.6} \\
(2 \%)\end{array}$ & $\begin{array}{c}\frac{21128.4}{408.9} \\
(2 \%)\end{array}$ & $\begin{array}{c}\frac{43537.6}{877.7} \\
(2 \%)\end{array}$ & $\begin{array}{c}\frac{32495.0}{649.9} \\
(2 \%)\end{array}$ \\
\hline Cobalt & 5,0 & $\begin{array}{c}\frac{19.4}{8.7} \\
(45 \%)\end{array}$ & $\begin{array}{c}\frac{32.2}{15.3} \\
(48 \%)\end{array}$ & $\begin{array}{c}33.4 \\
15.0 \\
(45 \%)\end{array}$ & $\begin{array}{l}\frac{30.5}{12.1} \\
(40 \%)\end{array}$ & $\begin{array}{c}30.4 \\
12.9 \\
(43 \%)\end{array}$ & $\begin{array}{c}\frac{19.9}{9.5} \\
(47 \%)\end{array}$ & $\begin{array}{c}29.4 \\
13.2 \\
(45 \%)\end{array}$ & $\begin{array}{c}\frac{21.0}{9.0} \\
(43 \%)\end{array}$ \\
\hline Manganese & n.1. & $\begin{array}{l}\frac{424.8}{227.5} \\
(54 \%)\end{array}$ & $\begin{array}{l}\frac{784.2}{392.8} \\
(50 \%) \\
\end{array}$ & $\begin{array}{l}\frac{699.4}{550.4} \\
(78 \%) \\
\end{array}$ & $\begin{array}{l}\frac{737.1}{511.3} \\
(69 \%) \\
\end{array}$ & $\begin{array}{l}\frac{811.8}{489.1} \\
(60 \%) \\
\end{array}$ & $\begin{array}{l}\frac{371.2}{300.2} \\
(81 \%) \\
\end{array}$ & $\begin{array}{l}\frac{645.4}{503.4} \\
(78 \%) \\
\end{array}$ & $\begin{array}{l}\frac{612.5}{367.5} \\
(60 \%) \\
\end{array}$ \\
\hline Copper & 3,0 & $\begin{array}{l}72.1 \\
54.2 \\
(75 \%)\end{array}$ & $\begin{array}{l}260.3 \\
200.9 \\
(77 \%)\end{array}$ & $\begin{array}{l}236.8 \\
174.5 \\
(74 \%)\end{array}$ & $\begin{array}{l}\frac{129.3}{115.1} \\
(89 \%)\end{array}$ & $\begin{array}{l}\frac{154.4}{93.3} \\
(60 \%)\end{array}$ & $\begin{array}{l}\frac{89.3}{75.1} \\
(84 \%)\end{array}$ & $\begin{array}{l}206.1 \\
152.4 \\
(74 \%)\end{array}$ & $\begin{array}{c}138.9 \\
83.4 \\
(60 \%)\end{array}$ \\
\hline Nickel & 4,0 & $\begin{array}{c}19.4 \\
12.7 \\
(65 \%)\end{array}$ & $\begin{array}{c}\frac{52.7}{31.2} \\
(59 \%)\end{array}$ & $\begin{array}{l}\frac{69.4}{41.4} \\
(60 \%)\end{array}$ & $\begin{array}{c}\frac{58.4}{42.4} \\
(73 \%)\end{array}$ & $\begin{array}{l}\frac{46.5}{33.5} \\
(72 \%)\end{array}$ & $\begin{array}{c}\frac{9.9}{6.1} \\
(61 \%)\end{array}$ & $\begin{array}{l}\frac{57.6}{34.6} \\
(60 \%)\end{array}$ & $\begin{array}{c}\frac{43.2}{31.1} \\
(72 \%)\end{array}$ \\
\hline Zinc & n.l. & $\begin{array}{c}\frac{2282.4}{850.1} \\
(37 \%) \\
\end{array}$ & $\begin{array}{l}3536.4 \\
1268.1 \\
(36 \%) \\
\end{array}$ & $\begin{array}{l}\underline{3353.2} \\
1198.4 \\
(36 \%) \\
\end{array}$ & $\begin{array}{l}\frac{2515.2}{1064.2} \\
(42 \%) \\
\end{array}$ & $\begin{array}{l}\frac{2976.1}{1235.1} \\
(42 \%) \\
\end{array}$ & $\begin{array}{l}\underline{2192.3} \\
1023.2 \\
(47 \%) \\
\end{array}$ & $\begin{array}{l}\underline{3235.6} \\
1164.8 \\
(36 \%) \\
\end{array}$ & $\begin{array}{l}2467.1 \\
1036.2 \\
(42 \%) \\
\end{array}$ \\
\hline \multicolumn{10}{|l|}{$\begin{array}{l}\text { Nonessential } \\
\text { (toxic) }\end{array}$} \\
\hline Cadmium & 0,01 & $\begin{array}{c}0.074 \\
0.05 \\
(68 \%) \\
\end{array}$ & $\begin{array}{r}1.92 \\
1.28 \\
(67 \%) \\
\end{array}$ & $\begin{array}{l}\underline{0.25} \\
0.15 \\
(60 \%) \\
\end{array}$ & $\begin{array}{r}1.33 \\
0.83 \\
(62 \%) \\
\end{array}$ & $\begin{array}{c}\underline{0.087} \\
0.05 \\
(57 \%) \\
\end{array}$ & $\begin{array}{c}\underline{0.075} \\
0.04 \\
(53 \%) \\
\end{array}$ & $\begin{array}{c}\underline{0.35} \\
0.21 \\
(60 \%) \\
\end{array}$ & $\begin{array}{l}\underline{0.078} \\
0.05 \\
(57 \%) \\
\end{array}$ \\
\hline Lead & 6,0 & $\begin{array}{l}\frac{31.1}{27.0} \\
(87 \%)\end{array}$ & $\begin{array}{c}\frac{72.9}{65.1} \\
(89 \%)\end{array}$ & $\begin{array}{l}\frac{78.1}{71.9} \\
(92 \%)\end{array}$ & $\begin{array}{c}\frac{37.3}{20.2} \\
(54 \%)\end{array}$ & $\begin{array}{c}\frac{65.4}{57.2} \\
(88 \%)\end{array}$ & $\begin{array}{c}\frac{52.2}{45.0} \\
(86 \%)\end{array}$ & $\begin{array}{l}\frac{72.3}{66.5} \\
(92 \%)\end{array}$ & $\begin{array}{l}\frac{31.5}{27.7} \\
(88 \%)\end{array}$ \\
\hline
\end{tabular}

Note: gross shape mobile form (\% of the mobile from gross);

* - MPS applies only to the mobile form; nl - not limited 
The high content of mobile forms of metal is revealed at sites with significant sedimentation, lower oxygen content and higher $\mathrm{pH}$ values - sites $3-5$, the smallest in the close to dam area - sites 1, 6 and in the plant opposite the hotel "Ternopil". Concerning nonessential metals, one can state that there is the pollution of silt of the pond with mobile cadmium (almost 60\%) and lead (almost $90 \%$ ). In this case, the content of mobile cadmium exceeds the permissible norm 5-80 times (at site 2 near the boat quay this norm was exceeded by 128 times), and lead - by 4.5-12.

According to the data presented in Table 5 on the content of metals in the bottom sediments, we make a forecast of the situation for the next two seasonal periods according to Markov chain theory. This theory allows one to make predictions of a factor, including the possibility of random effects on the environment, and investigates the greatest probability of presence of a factor in the most favourable state.Realization is carried out in software Matlab. Predicting the content of cobalt, copper, nickel and manganese in bottom sediments for the next 4 seasons, for possible monitoring of the situation.

Projected calculations of the content of cobalt in bottom sediments for two seasons for the near future.

$>\mathrm{A}=[19.4,32.2,33.4,30.5,30.4,19.9,29.4,21.0]$ $\mathrm{A}=$

$\begin{array}{lllll}19.4000 & 32.2000 & 33.4000 & 30.5000 & 30.4000\end{array}$ $19.9000 \quad 29.4000 \quad 21.0000$

>> $\mathrm{S}=19.4+32.2+33.4+30.5+30.4+19.9+29.4+21.0$ $\mathrm{S}=$

\subsection{0}

> $\mathrm{C}=[216.2000,216.2000,216.2000,216.2000$, 216.2000, 216.2000, 216.2000, 216.2000]

$\mathrm{C}=$

$$
\begin{array}{llll}
216.2000 & 216.2000 & 216.2000 & 216.2000 \\
216.2000 & 216.2000 & 216.2000 & 216.2000
\end{array}
$$$$
\text { ans }=
$$$$
\begin{array}{lllll}
0.0897 & 0.1489 & 0.1545 & 0.1411 & 0.1406
\end{array}
$$$$
\begin{array}{lll}
0.0920 & 0.1360 & 0.0971
\end{array}
$$$$
>\mathrm{B}=[0.0897,0.1489,0.1545,0.1411,0.1406 \text {, }
$$
$0.0920,0.1360,0.0971 ; 0.1489,0.1545,0.1411$, $0.1406,0.0920,0.1360,0.0971,0.0897 ; 0.1545$, $0.1411,0.1406,0.0920,0.1360,0.0971,0.0897$, $0.1489 ; 0.1411,0.1406,0.0920,0.1360,0.0971$, $0.0897,0.1489,0.1545 ; 0.1406,0.0920,0.1360$, $0.0971,0.0897,0.1489,0.1545,0.1411 ; 0.0920$, $0.1360,0.0971,0.0897,0.1489,0.1545,0.1411$, $0.1406 ; 0.1360,0.0971,0.0897,0.1489,0.1545$, $0.1411,0.1406,0.0920 ; 0.0971,0.0897,0.1489$, $0.1545,0.1411,0.1406,0.0920,0.1360]$

$\mathrm{B}=$

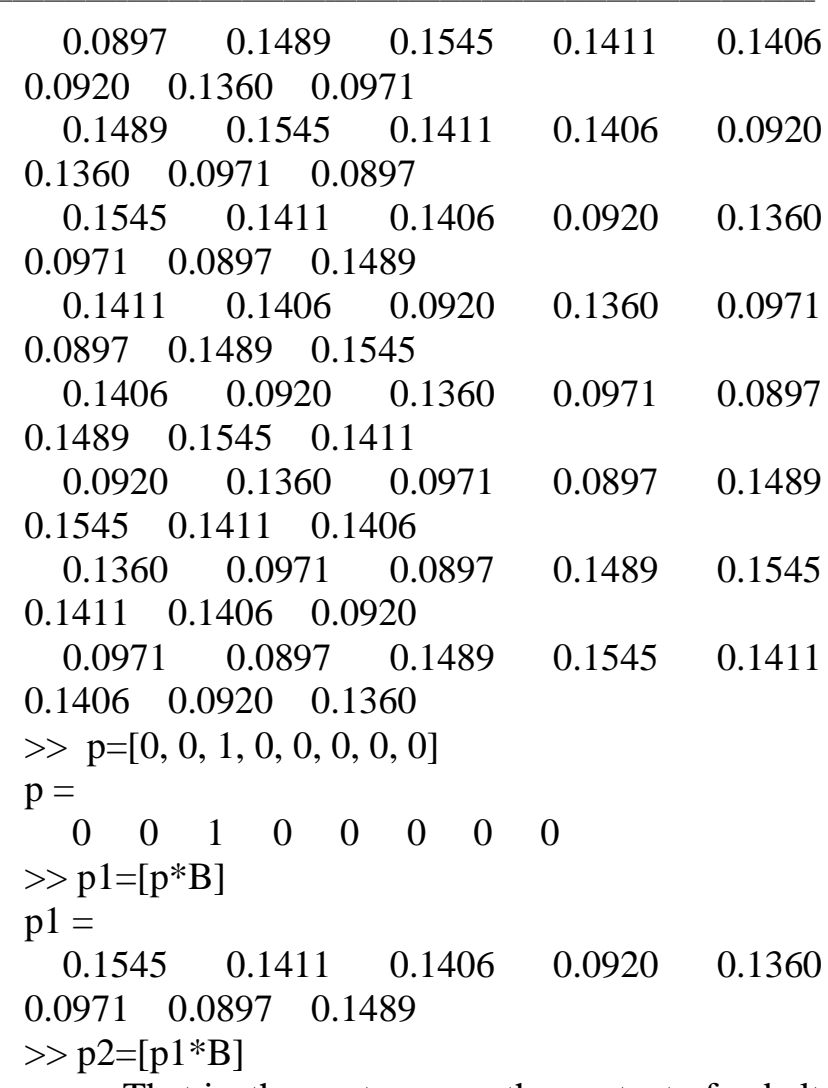

That is, the next season, the content of cobalt in the bottom sediment with the highest probability of 0.1545 will be 19.4

p2 $=$

$\begin{array}{lllll}0.1243 & 0.1254 & 0.1302 & 0.1254 & 0.1243\end{array}$ $\begin{array}{lll}0.1242 & 0.1220 & 0.1242\end{array}$

$>\mathrm{p} 3=[\mathrm{p} 2 * \mathrm{~B}]$

In 2020, the cobalt content in the bottom waters of the reservoir with the highest probability of 0.1302 will be 33.4 units. We will carry out a forecast of manganese content in the bottom sediment of the reservoir for the next two years.

>> $\mathrm{A}=[424.8,784.2,699.4,737.1,811.8,371.2$, 645.4, 612.5]

$\mathrm{A}=$

$\begin{array}{llll}424.8000 & 784.2000 & 699.4000 & 737.1000\end{array}$ $811.8000 \quad 371.2000645 .4000612 .5000$

$>>$

$\mathrm{S}=[424.8+784.2+699 \cdot 4+737 \cdot 1+811.8+371 \cdot 2+645.4$ $+612.5]$

$\mathrm{S}=$

$5.0864 \mathrm{e}+03$

$>\quad \mathrm{C}=[5.0864 \mathrm{e}+03, \quad 5.0864 \mathrm{e}+03, \quad 5.0864 \mathrm{e}+03$, $5.0864 \mathrm{e}+03,5.0864 \mathrm{e}+03,5.0864 \mathrm{e}+03,5.0864 \mathrm{e}+03$, $5.0864 \mathrm{e}+03]$

$\mathrm{C}=$

$1.0 \mathrm{e}+03 *$

$\begin{array}{lllll}5.0864 & 5.0864 & 5.0864 & 5.0864 & 5.0864\end{array}$ $5.0864 \quad 5.0864 \quad 5.0864$

> $\operatorname{rdivide}(\mathrm{A}, \mathrm{C})$

ans $=$ 


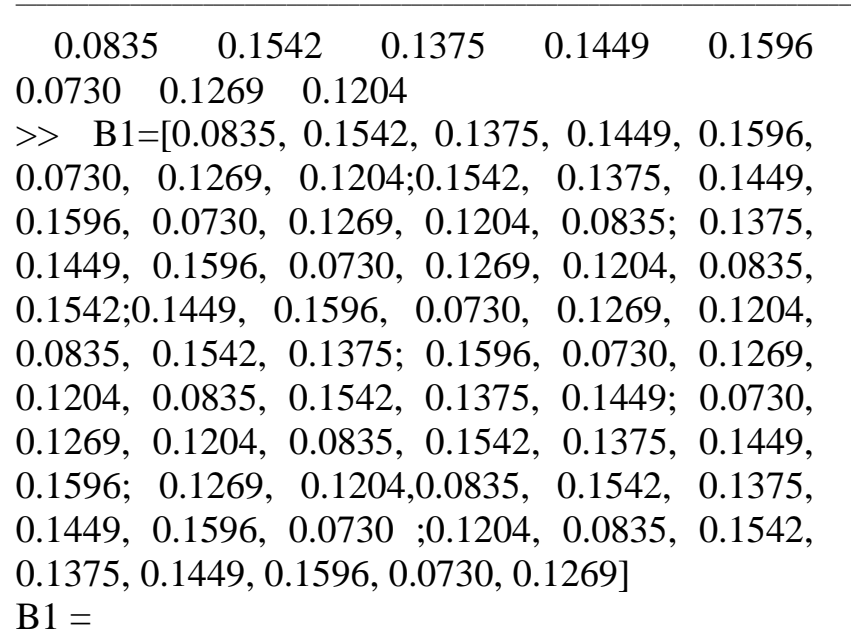

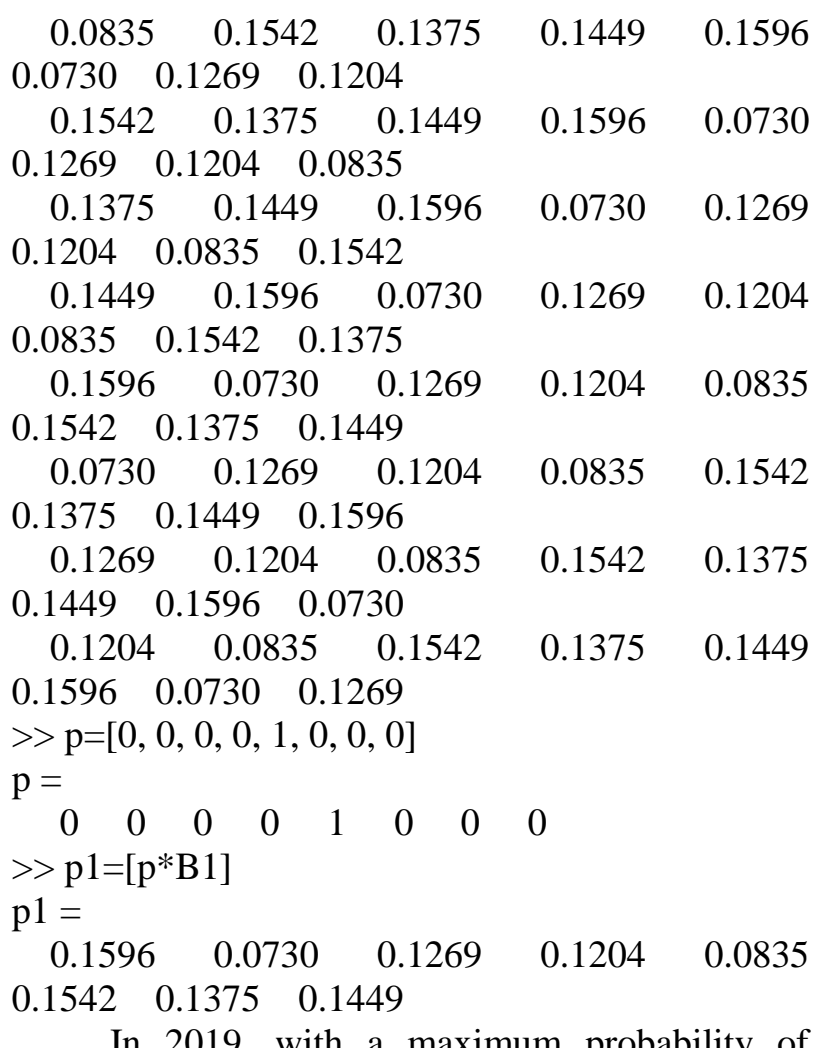

In 2019, with a maximum probability of 0.1596 , the content of manganese in the bottom waters of the reservoir will be 424.8 units. $>\mathrm{p} 2=[\mathrm{p} 1 * \mathrm{~B} 1]$

$\mathrm{p} 2=$

$$
\begin{gathered}
0.1190 \quad 0.1266 \quad 0.1246 \quad 0.12340 .1321 \\
0.12340 .1246 \quad 0.1266 \\
\text { In 2020, with a maximum probability of }
\end{gathered}
$$
0.1321 , the manganese content in the bottom waters of the reservoir will be 811.8 units.

Discussion. As a result of the complex hydroecological study of the reservoir Ternopil Pond, the ecological hazard of the content of certain substances and the ecotoxicological situation as a whole have been assessed by comparing the indicators with environmental norms and environmental quality standards (Gandzjura and Grubinko, 2008).
The water is mainly alkaline, which contributes to the presence of carbonic acid in the form of a hydrocarbonate ion, providing an environmentally acceptable gas regime of water and the absence of obsolescent phenomena. The reason for the alkalinity of the water is the decay of organic substances in the bottom layer and the silt, as well as the salinity of the reservoir with alkaline equivalents of flushing origin (Grubinko etal., 2013). One of the critical factors in the reservoir is the accumulation of ammonia in significant concentrations (Constableetal., 2013). The water most polluted ammonia is in the areas of its stagnation near the "Nadstavna Church", behind the island from the side of "Tsyganka", near the restaurant "Khutir" and near the boat station (excess MPC almost 30 times). Less contaminated due to leakage are areas near the dam (water drain - western and eastern - sites 6 and 1) (exceeding the MPC by 1015 times).The most polluted ammonia sludge is on the sites near the "Nadstavna Church", behind the island from the side of "Tsyganka" (exceeding the MPC by almost 100-150 times). High alkalinity of water contributes to the transition of a significant amount of ammonia to highly toxic ammonia, which degrades the ecotoxicological situation of the reservoir due to the significantly higher toxicity of ammonia compared with the ammonium ion(Romanenko 2015, Grubinko et al.,2013).

In the water, excess levels of sodium ions were found, which, along with the sum of ions of other metals, indicates the significant salinity of the pond, especially at sites of intense flushing from the shore: near the dam, from the side of the village of Bila and Krushelnytska St., from the restaurant "Khutir". The main source of salinity is the use on the roads and sidewalks of bulk salts and slags in the winter.

Polymetal contamination of sludge with high and biologically dangerous, except for iron, levels of their mobile forms and the excess over permissible levels in the most contaminated places is dozens of times above the norm. The excess of the norm of the content of the mobile mold for copper was found to be 24-86 times, nickel - from 2 to 17 times, cobalt - 4-8 times, and a high level of iron and zinc was established. The pollution of the sludge with mobile cadmium (almost $60 \%$ ) and lead (almost 90\%) was detected. In this case, the content of mobile cadmium exceeds the permissible norm by $5-80$ times (at the site 2 near the boat mooring this norm was exceeded by 128 times), and lead - by 4.5-12. A high level of content of mobile metal forms was established at sites with a significant blackening, lower oxygen content and higher values of $\mathrm{pH}$ - boat mooring, from the side 
of the village Bila, the beach "Tsyganka", the smallest was near the dam territory and the factory opposite the hotel "Ternopil" (Gumeniuk, 2003).

Using economic-mathematical modeling based on the theory of Markov chains, we have calculated the predicted values of the content of cobalt and manganese in the bottom sediment of the studied reservoir for the next two years, which will allow monitoring of the situation regarding the content of metals in the bottom sediment of the reservoir. Also, the method of correlationregression analysis investigated the effect of ammonium on the $\mathrm{pH}$ index of water, the effect is quite significant and is $86 \%$. The coefficient of elasticity was calculated on the basis of this value. The coefficient of elasticity suggests that with an increase in ammonia by $10 \%$, the $\mathrm{pH}$ index of water will decrease by $8 \%$ (Akin et al,2011; Budka, 2013).

Conclusion. Thus, regarding essential, and especially, nonessential metals, it is possible to state that pollution of the silts of the pond is polymetallic with a high and biologically dangerous, except for iron, share of their mobile forms and excess over the maximum permissible levels in the most contaminated places, ten times above the norm. In case of change in the hydrochemical balance (primarily $\mathrm{pH}$ index, carbon dioxide), the mobility of metals may increase, which will substantially exacerbate the virtually catastrophic contamination of the pond with extremely toxic and biologically hazardous metals. The areas most polluted with metals with a high degree of biological risk are the silty backwaters - site and the places of active surface runoff site. With the river runoff in the reservoir about half of the mobile metal form is brought, the rest is accumulating due to emissions. Knowing the predicted values of the content of such metals as manganese and cobalt, using the theory of prediction based on the theory of Markov chains, we can monitor the situation in the near future. If the hydrochemical balance is changed (first of all, $\mathrm{pH}$ index, carbon dioxide), the mobility of metals may increase, which will substantially aggravate the almost catastrophic contamination of the pond with highly toxic and biologically hazardous metals.

\section{References}

«Perelik zabrudnjujuchih rechovin dlja viznachennja himichnogo stanu masiviv poverhnevih i pidzemnih vod ta ekologichnogo potencialu shtuchnogo abo istotno zminenogo masivu poverhnevih vod». Nakaz Ministerstva ekologiï ta prirodnih resursiv Ukraïni 06.02.2017 № 45. Zareestrovano v Ministerstvi justiciï Ukraïni 20 ljutogo 2017 r.za № 235/30103. ["List of pollutants for the determination of the chemical state of the arrays of surface and groundwater and the ecological potential of an artificial or substantially changed massif of surface waters". Order of the Ministry of Ecology and Natural Resources of Ukraine, No.201 of 06.02.2017. Registered with the Ministry of Justice of Ukraine on February 20, 2017, No. 235/30103].

«Pravila ohoroni poverhnevih vod vid zabrudnennja zvorotnimi vodami». Zatverdzheno postanovoju Kabinetu Ministriv Ukraïni vid 25 bereznja 1999 r. N 465 [Rules for the protection of surface water from contamination by reverse water. Approved by the Resolution of the Cabinet of Ministers of Ukraine dated March 25, 1999 No. 465.].

Abubakar, A., Saleh, Y., Shehu, K., 2015. Heavy metals pollution on surface water sources in Kaduna metropolis, Nigeria. Science World Journal, 10(2), $1-5$.

Akin B. S., Atici T., Katircioglu H. Keskin F.: Investigation of water quality on Gökçekaya dam lake using multivariate statistical analysis, in Eskişehir. Environmental Earth Sciences. 63(6), 1251-1261 (2011). Doi: 10.1007/s12665-0100798-6

Brahman, K. D., Kazi, T. G., Afridi, H. I., Naseem, S., Arain, S. S., Wadhwa, S. K., Shah, F.: Simultaneous evaluation of the toxic levels of fluoride and arsenic species in the underground water of Tharparkar and possible contaminant sources. A multivariate study. Ecotoxicology and environmental safety. 89, 95-107 (2013).Doi: 10.1016/j.ecoenv.2012.11.023

Budka, A., Kayzer, D., Pietruczuk, K., Szoszkiewicz, K.: Zastosowanie wybranych procedur do wykrywania obserwacji nietypowych w ocenie jako- ści rzek. Infrastruktura i Ekologia Terenów Wiejskich. 3(II), 85-95 (2013).

Constable, M, Charlton, M., Jensen, F, McDonald K., Craig G. \& Taylor, K.W. (2010) An Ecological Risk Assessment of Ammonia in the Aquatic Environment, Human and Ecological Risk Assessment: An International Journal, 9(2), 527-548, doi: 10.1080/713609921).

Correl, D.L. (1998). The Role of Phosphorus in the Eutrophication of Receiving Waters: A Review. Journal of Environmental Quality, 28, 261-266. doi:10.2134/jeq1998.00472425002700020004x

Ermachenko, L.A. (1997). Atomno-absorbcionnyj analiz v sanitarno-gigienicheskih issledovanijah/ Pod red. Podunovoj L.G. [Atomic absorption analysis in sanitary-hygienic research]. Chuvashija, Cheboksary, (in Russian).

Gandzjura, V.P., Grubinko, V.V. (2008). Koncepcija shkodochinnosti $\mathrm{v}$ ekologiï [Concept of harmfulness in ecology]. Vid-vo TNPU im. V. Gnatjuka, Kiïv-Ternopil' (in Ukrainian).

Grubinko V.V., Gumeniuk, G.B., Volik, O.V., Svinko, J.M., Makkarti, F.M.G. (2013). Ekosistema zaregul'ovanoï vodojmi v umovah urbonavantazhennja: na prikladi Ternopil's'kogo 
vodoshovishha [Ecosystem of the regulated reservoir under the conditions of urban loading: on the example of Ternopil reservoir]. Vektor, Ternopil' (in Ukrainian).

Gumeniuk H., (2003). Rozpodil vazhkyh metaliv u hidroekosystemi prisnoi vodoimy (na prykladi Ternopilskoho stavu) [Heavy metals distribution in hydroecosystem of fresh water (on the example of Ternopil pond)] Ph.D. dissertation (ecology).Chernivtsi (in Ukrainian).

Directive 2000/60/ EU of the European Parliament and of the Council of 23 October 2000 establishing a framework for Community action in the field of water policy // Off. J. Eur. Community. - 2000. P. 327.

Malik, D., Singh, S., Thakur, J., Singh, R., Kaur, A.,Nijhawan,S., 2014. Heavy Metal Pollution of the Yamuna River: AnIntrospection. Int. J. Curr. Microbiol. App. Sci 3(10),856-863.

Manoj, K., Padhy, P., Chaundhury, S.,2012. Study of Heavy Metal Contamination of the River Water through Index Analysis Approach and Environmetrics. Bulletin of Environment, Pharmacology and Life Sciences Volume 1(10), 7-15.

Myslyva,T., Kot I., 2011. VazhkimetalyuvodakhmalykhrichokZhytomyrskohoPolisia [Heavy metals is small rivers of Zhutomyr region]. Bulletin of Zhytomyr National Agroecological University, 2, 5868 (in Ukrainian).

Nasrabadi, T., 2015. An index approach to metallic pollution in riverwaters. Int. J. Environ. Res. 9(1), 385-394.

Nesaratnam, Suresh T. (2014). Water Pollution Control. Hoboken: Wiley. Doi:10.1002/9781118863831.
Perales, H. V., Pena-Castro, J. M., \& CanizaresVillanueva, R. O. (2006). Heavy metal detoxification in eukaryotic microalgae. Chemosphere, 64, 1-10. doi:10.1016/j.chemosphere.2005.11.024.).

Rashed, M. N. (2001). Monitoring of environmental heavy metals in fish from Nasser Lake, Environ. Internat., 27, 27-33. doi.org/10.1016/S01604120(01)00050-2).

Rogatinsky R.M., Garmatiy N.M «Mathematical methods of market economy for specialistskibnetikov».Ternopil, Aston-2015. C. 205

Romanenko, O.V., Arsan, O.M., Kipnis, L.S., Sitnik, Ju.M. (2015) Ekologichni problemi Kiïvs'kih vodojm i prileglih teritorij [Environmental problems of the Kyiv reservoirs and adjoining territories]. Naukova Dumka, Kyiv (in Ukrainian).

Romanenko, V.D. (Ed.). (2006). Metodi gidroekologichnih doslidzhen' poverhnevih vod [Methods of hydroecological surveys of surface waters]. Logos, Kiyv (in Ukrainian).

Romanenko, V.D., (2015). Gidroekologichni problemi v umovah urbanizaciï [Hydroecological problems in the conditions of urbanization]. Naukovi zapysky TNPU im. V. Hnatiuka. Seria Biolohia [The Scientific Notes of Ternopil Volodymyr Hnatiuk National Pedagogical University. Series: biology], 3-4 (64), 18-21. (in Ukrainian).

Shannon, K.L., Lawrence, R.S., and McDonald, D. 2011. Antropogenic sources of water pollution: parts 1 and 2. In Water and Sanitation-Related Diseases and the Environment: Challenges, Interventions, and Preventive Measures. Edited by J.M.H. Selendy. John Wiley \& Sons, Inc., Hoboken (NJ, U.S.A.). pp. 289-302. doi.org/10.1002/9781118148594.ch2 